\title{
The Relationship between Age of Menarche and Body Mass Index (BMI) with Endometriosis Incidence at Dr. Mohammad Hoesin Palembang Period 2018 - 2020
}

\author{
Fatimah Usman ${ }^{*}$, Ghina Reza $\mathbf{S}^{2}$, Eka Handayani ${ }^{2}$
}

${ }^{1}$ Department of Obstetrics and Gynecology, Faculty of Medicine, Universitas Sriwijaya, Palembang, Indonesia

${ }^{2}$ Medical Education Study Program, Faculty of Medicine, Universitas Sriwijaya, Palembang, Indonesia

\section{A R T I C L E I N F O \\ Keywords: \\ Endometriosis \\ Cross-sectional \\ Age of menarche \\ Body mass index (BMI) \\ *Corresponding author: \\ Fatimah Usman \\ E-mail address: \\ titimusman@yahoo.com}

All authors have reviewed and approved the final version of the manuscript.

https://doi.org/10.37275/bsm.v6i4.477

\begin{abstract}
A B S T R A C T
Background. Endometriosis is the presence of endometrial glands and stroma outside the uterus. This study aims to analyze the relationship between age of menarche and body mass index (BMI) with the incidence of endometriosis. Methods: This study is an analytical observational study with a cross-sectional approach. The samples taken in this study were post-operative patients with gynecological disorders at Dr. Mohammad Hoesin General Hospital Palembang. The sample taken in this study was 62 respondents during the period 2018-2020 with a simple random sampling technique based on inclusion criteria. The research data was processed and analyzed by univariate and bivariate with Chisquare test using SPSS application. Results: Most of the respondents with endometriosis experienced at the age of menarche $<12$ years $(91.3 \%)$ and had a non-obese BMI (73.3\%). There was a significant relationship between the age of menarche and the endometriosis incidence $(p=0.039)$. There was no statistically significant relationship between body mass index (BMI) and the endometriosis incidence $(p=1,043)$. Conclusion: Early menarche can increase the risk of endometriosis. The majority of women with endometriosis in this study had a BMI in the non-obese category (BMI <25).
\end{abstract}

\section{Introduction}

Endometriosis is the presence of endometrial glands and stroma outside the uterus. Endometriosis is often found in the pelvic peritoneum, ovaries, and uterosacral ligaments. ${ }^{1}$ Endometriosis is an estrogendependent disease, in which the growth and development of endometrial tissue require stimulation of the hormone estrogen., one of the main sources of estrogen is fat (adipose) tissue. ${ }^{3}$

The prevalence of endometriosis reaches $6-10 \%$ in the general female population worldwide. ${ }^{4}$ According to a survey conducted in the United Kingdom and the United States of women with endometriosis, it was found that $70-71 \%$ had pelvic pain, $71-76 \%$ had dysmenorrhea, 44\% had dyspareunia, and 15-20\% had infertility. ${ }^{5}$ The incidence of endometriosis in Asian countries reaches $15 \%$ and is estimated to be higher than in the Caucasian and African-American races. ${ }^{6}$

In Indonesia, the incidence of endometriosis is still very diverse and influenced by many factors. At Dr. Hospital. Moewardi the incidence of endometriosis is 
estimated at $13.6 \%$ and in Dr. Sutomo estimated $37.2 \%$ in infertile women. The gold standard in establishing a definite diagnosis of endometriosis requires surgery either through laparotomy or laparoscopy so that the incidence of endometriosis is difficult to know with certainty if only in terms of clinical symptoms.

According to recent research, risk factors such as menstrual factors (early age of menarche, short menstrual cycles, and heavy menstrual volume), reproductive factors (low parity), genetic factors, and body mass index (BMI) are known to cause endometriosis. .7.8 According to Sohn, several countries such as Indonesia tend for girls to experience early menarche. 9 Several studies have shown that the early age of menarche (<12 years) will increase estrogen exposure and increase the possibility of menstrual reflux so that the possibility of endometriosis in a woman will increase. ${ }^{7}$ Women with a high BMI tend to have more adipose tissue, which can increase the risk of endometriosis. The purpose of this paper is to determine the relationship between age of menarche and body mass index (BMI) with the incidence of endometriosis in Dr. Mohammad Hoesin General Hospital Palembang.

\section{Methods}

This research is an observational analytic study with a cross-sectional design. The data used in this study is secondary data from the medical record installation of Dr. Mohammad Hoesin General Hospital Palembang. The population of this study was postoperative patients with gynecological disorders at Dr.
Mohammad Hoesin General Hospital Palembang. period 2018 -2020. The sample size taken in this study was 62 respondents with a simple random sampling technique. This research was conducted at the medical record installation of Dr. Mohammad Hoesin General Hospital Palembang from October to December 2021.

The independent variables in this study were age of menarche and body mass index (BMI), while the dependent variable was endometriosis. The data that has been collected will be analyzed through the SPSS application in univariate and bivariate ways. The bivariate analysis used was the Chi-square test $(\mathrm{p}=$ 0.05). The data is presented in the form of tables and narratives.

\section{Results}

The number of samples obtained in this study was 62 respondents, where the case group was taken from postoperative patients with gynecological disorders who had been diagnosed as endometriosis and postoperative patients with gynecological disorders other than endometriosis as a non-case group at RSUP Dr. Mohammad Hoesin General Hospital Palembang in 2018-2020.

\section{Distribution of endometriosis patients}

In table 1 below, it can be seen that from a total of 62 respondents, 46 people $(74.2 \%)$ were diagnosed with endometriosis, where the majority of respondents in this study were women with endometriosis.

Table 1. Frequency distribution of endometriosis patients

\begin{tabular}{|c|c|c|}
\hline Endometriosis & Total (N) & Percentage (\%) \\
\hline Endometriosis & 46 & 74.2 \\
\hline Non-Endometriosis & 16 & 25.8 \\
\hline Total & 62 & 100 \\
\hline
\end{tabular}

\section{Distribution of respondents based on age of menarche}

In table 2 it can be seen that the majority of respondents in this study experienced at the age of menarche $\geq 12$ years $(62.9 \%)$ and $(37.1 \%)$ respondents experienced menarche before the age of 12 years old. 
Table 2. Distribution of respondents based on age of menarche

\begin{tabular}{|c|c|c|}
\hline $\begin{array}{c}\text { Age of } \\
\text { Menarche }\end{array}$ & $\begin{array}{c}\text { Total } \\
\text { (N) }\end{array}$ & Percentage (\%) \\
\hline$<12$ years old & 23 & 37.1 \\
\hline$\geq 12$ years old & 39 & 62.9 \\
\hline Total & 62 & 100 \\
\hline
\end{tabular}

\section{Distribution of respondents based on Body Mass Index (BMI)}

Based on table 3 the majority of research respondents have BMI with categories underweight as many as 21 people (33.9\%), followed by BMI normal category as many as nine people (14.5\%), overweight as many as 15 people (24.2\%), obesity category I as many as eight people (12.9\%) and category II obesity as many as nine people (14.5\%).

Table 3. Distribution of respondents based on Body Mass Index (BMI)

\begin{tabular}{|c|c|c|}
\hline BMI & $\begin{array}{c}\text { Total } \\
\text { (N) }\end{array}$ & $\begin{array}{c}\text { Percentage } \\
\text { (\%) }\end{array}$ \\
\hline$<18.5$ (Underweight) & 21 & 33.9 \\
\hline $18.5-22.9$ (Normal) & 9 & 14.5 \\
\hline $23-24.9$ (Overweight) & 15 & 24.2 \\
\hline $25-29.9$ (Obesity I) & 8 & 12.9 \\
\hline$\geq 30$ (Obesity II) & 9 & 14.5 \\
\hline Total & 62 & 100 \\
\hline
\end{tabular}

\section{Relationship between age of menarche and endometriosis}

Based on the results of the analysis in table 4, the $\mathrm{p}$-value is 0.039 ( $\mathrm{p}$-value < 0.05), which means that there is a statistically significant relationship between the age of menarche and the incidence of endometriosis in Dr. Mohammad Hoesin General Hospital Palembang. In this study, the prevalence ratio $(\mathrm{PR})$ was 1.424, which means that women with early menarche $(<12$ years) have a risk of endometriosis 1.424 times greater than women who experience menarche at the age of 12 years old.

Table 4. The results of analysis of the relationship between age of menarche and endometriosis incidence

\begin{tabular}{|c|c|c|c|c|c|c|}
\hline \multirow{3}{*}{$\begin{array}{c}\text { Age } \\
\text { of Menarche }\end{array}$} & \multicolumn{4}{|c|}{ Endometriosis } & & \multirow[b]{2}{*}{ P-Value } \\
\hline & \multicolumn{2}{|c|}{ Endometriosis (Sample) } & \multicolumn{2}{|c|}{$\begin{array}{c}\text { Non-Endometriosis } \\
\text { (Comparison) }\end{array}$} & PR & \\
\hline & $\mathrm{n}$ & $\%$ & $\mathrm{n}$ & $\%$ & \multirow{4}{*}{1,424} & \multirow{4}{*}{0.039} \\
\hline$<12$ years & 21 & 91.3 & 2 & 8.7 & & \\
\hline$\geq 12$ years & 25 & 64.1 & 14 & 35.9 & & \\
\hline Total & 46 & 74.2 & 16 & 25.8 & & \\
\hline
\end{tabular}




\section{Relationship between Body Mass Index (BMI) and endometriosis}

Based on the results of the analysis in table 5 , a pvalue of 1,000 was ( $\mathrm{p}$-value $>0.05$ ) which means that there is no statistically significant relationship between BMI and the incidence of Endometriosis at the RSUP
Dr. Mohammad Hoesin General Hospital Palembang. This study shows a PR value $=1.043$ which means that women with a body mass index (BMI) in the obese category $(\mathrm{BMI} \geq 25)$ have a 1.043 times greater risk of developing endometriosis than non-obese BMI women $(\mathrm{BMI}<25)$.

Table 5. The results of analysis of the relationship between body mass index (BMI) and endometriosis incidence

\begin{tabular}{|c|c|c|c|c|c|c|}
\hline \multirow{3}{*}{ Body Mass Index (BMI) } & \multicolumn{4}{|c|}{ Endometriosis } & \multirow[b]{2}{*}{ PR } & \multirow[b]{2}{*}{ P-Value } \\
\hline & \multicolumn{2}{|c|}{$\begin{array}{c}\text { Endometriosis } \\
\text { (Sample) }\end{array}$} & \multicolumn{2}{|c|}{$\begin{array}{c}\text { Non-Endometriosis } \\
\text { (Comparison) }\end{array}$} & & \\
\hline & $\mathrm{n}$ & $\%$ & $\mathrm{n}$ & $\%$ & \multirow{4}{*}{1,043} & \multirow{4}{*}{1,000} \\
\hline Obesity (BMI $\geq 25$ ) & 13 & 76.5 & 4 & 23.5 & & \\
\hline Non-Obesity $(\mathrm{BMI}<25)$ & 33 & 73.3 & 12 & 26.7 & & \\
\hline Total & 46 & 74.2 & 16 & 25.8 & & \\
\hline
\end{tabular}

\section{Discussion}

Based on the age of menarche variable in this study, a p-value of 0.039 was obtained which means that there is a statistically significant relationship between the age of menarche and the incidence of endometriosis in Dr. Mohammad Hoesin General Hospital Palembang. The results of this study are following the research of Augoulea and Mukti ( $p$-value 0.007) which showed that there was a relationship between the age of menarche and the incidence of endometriosis. ${ }^{11,12}$ According to Sampson's theory, the incidence of endometriosis can be caused by menstrual reflux whereas women who have more menstrual opportunities will be more at risk for experiencing endometriosis. ${ }^{13}$ Women with early age of menarche (<12 years) will be exposed to estrogen longer and the possibility of menstrual reflux will be greater, thus increasing the risk of endometriosis. ${ }^{7}$ In the body mass index (BMI) variable, the p-value obtained in this study was 1.000 which means that there is no statistically significant relationship between body mass index (BMI) and obesity category (BMI 25) on the incidence of endometriosis in Dr. Mohammad Hoesin General Hospital Palembang.

The results of this study are in agreement with a retrospective in China conducted by Tang on women with endometriosis, in which the study showed that there was no significant relationship between body mass index (BMI) and the incidence of endometriosis. However, obese women are more at risk of developing endometriosis than women with normal BMI. ${ }^{14}$ Similar results were also found in Bouzari's study of 417 women with endometriosis aged 15-45 years who had undergone laparoscopy or laparotomy (p-value 0.16). The study showed that there was no significant relationship between BMI and the incidence of endometriosis at the time of diagnosis. ${ }^{9}$ study a casecontrol in Australia by Holdsworth-Carson in women with pelvic pain who had undergone laparoscopy, stated that women with normal BMI were more likely to suffer from endometriosis when compared to underweight. 9,15

The main source of estrogen in women, one of which comes from fat or adipose tissue, where body fat can affect the menstrual cycle which can trigger endometriosis. ${ }^{16.1}$ Women with high BMI tend to have more adipose tissue so that estrogen production will increase which can increase the risk of endometriosis. Meanwhile, women with lower BMI tend to have less adipose tissue so that estrogen production will decrease. This can cause menstrual cycles to become 
irregular. ${ }^{17}$

The difference in the study sample size and the completeness of the available data may lead to mixed results in several studies. This study has the advantage that the endometriosis cases taken are endometriosis patients who have been confirmed by surgery or surgery, whereas most of the previous research studies of endometriosis cases taken were based on selfreported reports. Endometriosis can occur asymptomatically (without symptoms) so that the diagnosis of endometriosis cases made through personal reports without any assessment based on surgery can lead to misclassification of endometriosis, where some cases of endometriosis may be classified in the non-case group. However, this study has limited the definition of endometriosis cases, where the samples taken were patients who had confirmed endometriosis through either laparoscopic or laparotomy surgery. Differences in sampling in cases of endometriosis incidence may cause differences in the results of the study. ${ }^{14,17}$ In addition, this study also presents the prevalence ratio (PR) value to reflect the strength or magnitude of the relationship between a risk factor and the incidence of a disease.

The limited research time became an obstacle in collecting research data so the number of samples obtained was limited. In addition, this study uses secondary data in the form of patient medical records, where some data such as a history of dysmenorrhea, family history of endometriosis, and menstrual patterns such as the amount of menstrual blood have not been fully recorded in this study.

\section{Conclusion}

The women with endometriosis in this study experienced the most menarche at older ages 12years and non-obese BMI (BMI <25). In this study, there was a statistically significant relationship between the variable age of menarche and the incidence of endometriosis. However, there was no statistically significant relationship between body mass index (BMI) variables and the incidence of endometriosis.

\section{References}

1. Hoffman BL, Schorge JO, Bradshaw karan D. Endometriosis. In: Williams Gynecology. 3rd ed. New York: McGraw-Hill Education; 2016; 230.

2. Hendarto H. Endometriosis From the theoretical aspect to clinical treatment. Surabaya: Unair Publishing and Printing Center (AUP); 2015; 6.

3. Hanina SM, Fauzi A, Krisna R. Relationship between Obesity and endometriosis in Dr. Mohammad Hoesin Palembang Period 1 January 2015-31 December 2016. Maj Kedokt Sriwij. 2018; 50(4): 107-13.

4. Liu Y, Zhang W. Association between body mass index and endometriosis risk: A metaanalysis. Oncotarget. 2017; 8(29): 46928-36.

5. Fatimah D, Hutagaol IEB, Romus I. Profile of endometriosis cases at Arifin Achmad Hospital, Riau Province Period 1 January 2012 - 31 December 2016. Jik. 2018; 12(1): 42-3.

6. Yamamoto A, Johnstone EB, Bloom MS, Huddleston HG, Fujimoto VY. A higher prevalence of endometriosis among Asian women does not contribute to poorer IVF outcomes. J Assist Reprod Genet. 2017; 34(6): 765-74.

7. Saha R, Kuja-Halkola R, Tornvall P, Marions L. Reproductive and lifestyle factors associated with endometriosis in a large cross-sectional population sample. J Women's Heal. 2017; 26(2): 152-8.

8. DeCherney AH, Nathan L, Laufer N, Roman AS. Endometriosis. In: Current diagnosis \& treatment obstetrics \& gynecology. 11th ed. New York: McGraw-Hill; 2013; 4775.

9. Sohn K. The trend in age of menarche in Indonesia: Birth cohorts 1944-1988. J Biosoc Sci. 2015; 47(3): 407-12.

10. Islamy A, Farida F. Factors affecting menstrual cycle in level iii adolescent girls. J Mental Nursing. 2019; 7(1): 13.

11. Augoulea A, Kindis A, Karopoulou E, Tsoltos N, Kaparos G, Tsakonas E, et al. Age of menarche 
and oxidative stress markers in women with endometriosis. SN Compr Clin Med. 2020; 2(1): 69-74.

12. Treloar SA, Bell TA, Nagle CM, Purdie DM, Green AC. Early menstrual characteristics associated with subsequent diagnosis of endometriosis. Am J Obstet Gynecol. 2010; 202(6): 534.e1-534.e6.

13. Tang Y, Zhao M, Lin L, Gao Y, Chen GQ, Chen $\mathrm{S}$, et al. Is body mass index associated with the incidence of endometriosis and the severity of dysmenorrhoea: A case-control study in China? BMJ Open. 2020; 10(9): 1-6.

14. Lasabuda T, Wowor PM, Mewo Y. Overview of Body Mass Index (BMI) of the Al-Fatah Mosque Congregation in Malalayang. J e-Biomedicine. 2015; 3(3): 9-12.

15. Bustam FP. Relationship between Obesity and menstrual cycle. Relationship between obesity and bronchial asthma. Fauziah Paramita Bustam Medical Faculty, Univ Lampung. 2015; 2(4): 481-5.

16. Islamy A, Farida. Factors that influence the menstruation cycle in young women level iii. J Mental Nursing. 2019; 7(1): 13-8.

17. Farland L V., Missmer SA, Bijon A, Gusto G, Gelot A, Clavel-Chapelon F, et al. Associations among body size across the life course, adult height and endometriosis. Hum Reprod. 2017; 32(8): 1732-42. 